\title{
THE FASCIST MIMESIS OF SPANISH INTERNATIONAL LAW AND ITS VITORIAN AFTERMATH (1939-1953)
}

\author{
Ignacio de la Rasilla del Moral
}

Post-Doctoral Max Weber Fellow in Law, European University Institute, Florence.

Adjunct Professor NYU (Florence)

\section{Introduction}

"We are not going to argue with the regulars over the tasteless spoils of a dirty banquet. Our place is outside in the open air, under the cloudless heavens, with our weapons pointing starward over our shoulders. Let others continue with their feasts. Here, outside, in tense, fervent and sure vigilance, we already anticipate the dawn in the joy of our entrails" ${ }^{1}{ }^{1}$ Less than six years, half a million deaths and more than a million exiles lie between the last paragraph of the founding speech of the Spanish Falange and Generalísimo Franco's signature of his last war dispatch: "On this day, with the Red Army captured and disarmed, the national troops have reached their ultimate military objectives. The war has ended". By the $1^{\text {st }}$ April 1939, José Antonio Primo de Rivera, the man who had feverishly pronounced the ominous words of the founding speech of the Spanish Falange in Madrid's Teatro de la Comedia in October 1933 had long been shot dead by a firing squad in a Republican prison. Soon after the end of the Spanish Civil War his name appeared on a par with Hans Kelsen in an article published in La revue international de la théorie du droit, "The Pure Theory of Law and the Political Thought of José Antonio Primo de Rivera."2 The author of this article, which coupled the father of the normativist strand of legal positivism and neo-Kantian legal theorist with the notorious son of the Spanish military dictator who ruled Spain under Alphonse XIII from 1923 to 1930, was no neophyte to the works of the Viennese master, but the same legal theorist who had made it possible for an abridged version of The Pure Theory of Law to appear published in Spanish before it was in any other language - even German - back in 1933. ${ }^{3}$

Distorted by a domestic regime that made ultra-Catholicism and anti-communism the flagship of its foreign policy, Spanish international law academia remained a loyal fellowtraveler of the authoritarian rule born from the ashes of a war that was soon legislatively defined as "a popular revolt to prevent a criminal conspiracy from making Spain a slave to

\footnotetext{
1. José Antonio Primo de Rivera, "Discurso de la Fundación de Falange Española" in Jose Antonio Primo de Rivera, Escritos y discursos. Obras Completas 1922-1936 (recopilación de Agustín del Río Cisneros), Tomo I, Delegación Nacional de la Sección Femenina de F. E. T. y de las J. O. N. S., Madrid, 1959 at pp. 189-198.

2 Luis Legaz Lacambra, "La théorie pure du droit et la pensée politique de José Antonio Primo de Rivera", Révue internationale de la théorie du droit, Paris, 1939.

${ }^{3}$ Hans Kelsen, El método y los conceptos fundamentales de la teoría pura del Derecho, (trad. Luis Legaz Lacambra) Ed. Revista de Derecho Privado (1933)
} 
the Soviet tyranny". ${ }^{4}$ In the aftermath of the Spanish Civil War, the ranks of Spanish academia appeared decimated by the effects of death and exile. ${ }^{5}$ Imprisonment and university purges ${ }^{6}$ were soon to complete the elimination of all vestiges of Republicanism from the twelve universities that existed in the country. Only those "addicted to the regime," some of whom benefitted from vacant chairs as war booty for their services in the victory against the "Anti-Spain crusade," saw their careers boost in an atmosphere of forced entanglement in an imagery of anti-liberal, nationalist and ultra-catholic references, which also extended its influence to international legal studies in Spain. This prevailing intellectual climate was intensified by a wave of exaltation of the fatherland, any attack on which, by then, was portrayed as the continuation of the highly pernicious effects of foreign intellectual mimetism on Spanish traditionalist thought, or else as crude Marxism. These found their ultimate propagandist expression in the barely caricatural myth of the existence of a nebulous "Judean-Masonic-Marxist" international conspiracy against Spain. For the new ruling Falangist intelligentsia, Marxist ideology had to be considered the antithesis of the "Spanish genius". The cautionary tale of the recent Spanish Civil War was brandished to show that Marxism was a "fairly uncomfortable waiting-room to hell".7

Between 1939 and 1953, Spanish foreign policy confronted an international sphere that was undergoing radical transformations. To allow for a better understanding of the evolution of Spanish academia's approach to international law that went hand in glove with the design of Spanish foreign policy during this period, this essay is divided in two sections. I first introduce the role played by the reception of Carl Schmitt's works among Spanish political and legal theorists with a marked internationalist orientation as illustrative of the mermaid's song of the imperial temptation of the Axis powers that characterized Spanish international law from 1939 to 1943-5. While the intellectual reception of Carl Schmitt in Spain was primarily aimed at instrumentally nurturing the theoretical legitimization of the new authoritarian regime, it also mirrored the acute climax of intellectual fascistization of Spain's combative counter-revolutionary elites between 1939 and 1943-5. This period of fascist mimesis is, moreover, examined through the influence of the book Reivindicaciones de España and other similar works with neocolonialist credentials penned by Spanish international lawyers during the period. Although this pro-fascist breed of thought was gradually submerged under the rise of a more traditional nationalist purist orientation, this long triennium and its slow historically autarchic aftermath cast a long shadow over the evolution of international law in Spain for many more years to come.

In the second part of the essay, I focus on the Spanish transition from autarchy to international realignment with the West that took place from 1943-45 to 1953. I examine how a climate of severe intellectual repression and organically nationalist-directed scientific work in Spain and the nationalist reaffirmation of a culture grounded in Catholic conservatism and traditionalism fostered the adoption of a marked thematic orientation

\footnotetext{
${ }^{4}$ Ley 1 de marzo de 1.940 (B.O.E. no 12.667) para la Represión del Comunismo y la Masonería. See, further, Julius Ruiz, Franco's Justice. Repression in Madrid after the Spanish Civil War, Oxford University Press, (2005)

${ }^{5}$ See Henry Kamen, The Disinherited: Exile and the Making of Spanish Culture (1492-1975) Harper Collins, New York, (2007)

${ }^{6}$ See Jaume Claret Miranda El atroz desmoche. La destrucción de la Universidad española por el Franquismo, 1936-1945 (prólogo de Josep Fontana), Ed. Crítica, Barcelona (2006)

7 José Cortes Grau “Nuestro anti-comunismo” 35-36 Revista de Estudios Políticos (1947) pp.129-137
} 
towards natural law and the reinstatement of the Siglo de Oro's Salamanca School among Spanish international lawyers. This orientation equated well with the prevailing atmosphere of atavistic Spanish nationalist cultural forms drawn from the mythology of Reconquest, Counter Reformation and Empire, as well as with the myth of the Crusade against the "anti-Spain" that had been used as a justification for the Civil War in the name of national reunification. The fruitful intellectual revival of the Spanish Siglo de Oro was, however, not unrelated to more concrete Spanish foreign policy goals. These included the defense of the Hispanidad and the renewal in importance of a sound diplomatic policy towards South America during the period of Spanish autarky. Such a Spanish neocolonialist orientation vis-à-vis its former colonies had not been alien to the cultivation of the Seconda Scholastica by Spanish international legal academia during the interwar years. The Vitorian aftermath of the Fascist mimesis of Spanish international law helped to anchor the Franco regime's preferred strategic portrayal of Spain as the last bastion of traditional European Catholic values after the Second World War. It also contributed to reinforcing the external image of Spain as the only European country that had successfully resisted the spread of Russian imperialism and atheist Marxism.

\section{The Temptation of the Axis and the Fascist Mimesis of Spanish International Law}

The first issue of Revista de Estudios Políticos featured in a 1941 translation of Carl Schmitt's "The concept of Empire in International Law". ${ }^{8}$ Its publication mirrored the epochal ascendancy of the fascist mimesis in Spanish international legal academia and was consonant with the "will of Empire" featured in the third of the original Spanish Falange's twenty-seven program points. This essay, which celebrated how "the action of the Führer has provided political reality, historical truth and a splendid future to the idea of our empire in International Law", ${ }^{9}$ was presented to the Falangist intelligentsia as an example of "how the profound transformations of the world we are living through are accompanied by the renovation of political concepts".10 The Schmittian defense of the "concept of empire as the cornerstone of international law"11 was theoretically grounded on the notion of Weltanschauung ${ }^{12}$ and on the related claim that any domestic political changes in a State should result in changes in the international legal community. The latter was a corollary of Schmitt's critique of the liberal international legal order epitomized by Versailles' model of international law, which he decried as one stemming from abstractnormativism. This Schmittian line of international legal thought was in perfect consonance with the editorial line of the Franco regime's thinktank, Instituto de Estudios Politicos. ${ }^{13}$

In the aftermath of the Spanish Civil War, Schmitt's intellectual relationship to Spain was already long-standing. As early as the late 20s, relevant Spanish intellectual figures had commented upon his political thought, and during the 30s some of his fundamental books

\footnotetext{
${ }^{8}$ Carl Schmitt, "El concepto de imperio en el Derecho internacional" (trad. de Javier F. Conde) 1 Revista de Estudios Políticos, pp. 83-101.

9 Ibid. at 100

10 Ibid. at 83

11 Ibid. at 99

12 See Anthony Carty, “Carl Schmitt's critique of Liberal International Legal Order Between 1933 and 1945” 14 Leiden Journal of International Law (2001) pp. 25-36

13 Agustin José Menendez "From Republicanism to Fascist Ideology Under the Early Franquismo" in Joerges, Christian and Ghaleigh, Navraj Singh (eds.) Darker Legacies of Law in Europe: The Shadow of National Socialism and Fascism Over Europe and Its Legal Traditions, Hart Publishers (2003 ) pp.337-360.
} 
had been translated into Spanish. ${ }^{14}$ Moreover, in the late 20s Schmitt himself had engaged in a dialogue with the "theologized politics of dictatorship"15 of Juan Donoso Cortes, who had been a mid-19th century reactionary Spanish philosopher. Donoso's international reputation, as well as the role that his works played in the Francoist intelligentsia's debates, ${ }^{16}$ especially thanks to their re-interpretation through monarchical traditionalist lenses by Alvaro d'Ors, ${ }^{17}$ owes considerably to this Schmittian affiliation. ${ }^{18}$ Yet, Schmitt's longstanding relationship with Spain, which has been portrayed as one of "reciprocal effect," 19 continued far beyond the Second World War. ${ }^{20}$ At the time of Spain's period of experimentation with the State constitution in the early 40s, however, Spanish politicoacademic elites were mostly interested in the possibilities that Schmitt's work offered for the theoretical legitimatization of the Franco regime. Other political services to which the Falangist intelligentsia put Schmitt's opus during the 40s include his contribution to the theoretical construction of the notion of "organic democracy". This became the legitimizing political umbrella under which the Franco regime attempted to present itself during its process of gradual strategic realignment with the Western world in the early stages of the Cold War. As its author, Schmitt also joined the renewal in historical naturalist production by Spanish international legal academia during the 40s and 50s. Although a "scholastic" or medieval interpretation of Vitoria was at the heart of Schmitt's reconstruction of the European public order in terms of friend/enemy, ${ }^{21}$ his existentialism would become tempered on Christian ius-naturalist grounds in its domestic political reception in Spain.

During this early Franquoist period, in which "Carl Schmitt's theoretical positions are not simply assumed, but yet will serve as inexcusable reference for the legal-political debate of the epoch",22 his main works were mainly translated into Spanish by his foremost Spanish disciple, Francisco Javier Conde (1908-1974). Conde attempted in his own work to (literally) "glocalize" 23 Schmitt's theoretical foundations so as to better allow their adaptation to the conforming features of the new Spanish political regime. Adapted to the transcendental legitimacy basis - creatio a Deo - Schmitt's conceptual schemes played a pivotal role in the regime's political theory, which was in urgent need of a solid theoretical basis to legitimize its coup d'état from a totalitarian perspective. Conde also became the

14 Vid, among others, C.Schmitt, La defensa de la constitución, (trad. M.Sánchez Sarto) Ed. Labor, Barcelona (1931). C. Schmitt, La Teoría de la Constitucion (trad. F.Ayala) Editorial Revista de Derecho Internacional Privado, 1934

15 See Jan Werner Muller, A Dangerous Mind: Carl Schmitt in Post-War European Thought, Yale University Press, New Haven and London (2003), at 133.

${ }^{16}$ Jose Corts Grau, “Perfil actual de Donoso Cortés”, 19-20 Revista de Estudios Políticos (1945), pp. 74-120.

17 See José Antonio López García, "La presencia de Carl Schmitt en España”, Revista de estudios políticos 91, (1996) pp. 139-168, at 140.

${ }_{18}$ This long relationship would culminate in his book C. Schmitt, Donoso Cortés in gesamteuropäischer Interpretation, Greven Verlag, Cologne (1950).

19 José María Beneyto: Politische Theologie ais politische Theorie. Eine Untersuchung zur Rechts- und Staatstheorie Cari Schmitts und zu ihrer Wirkungsgeschichte in Spanien, Dunckcr und Humblot, Berlín, 1983, at 18. See also A.Truyol y Serra, Historia de la Filosofía del Derecho y del Estado, vol. 3. Idealismo y positivismo (2004), at 313-319.

20 See Tommissen, "Miroir de Carl Schmitt", 16 Cahiers Vilfredo Pareto (1978) pp. 220-275.

${ }^{21}$ For the influence of Carl Schmitt's interpretation of Vitoria in the domestic debate over Spanish tradition as an explanation of the international isolationism of Spain, see José Antonio López García, "La presencia de Carl Schmitt en España", op. cit. note 35, at 147.

22 López García, op.cit. at 140.

${ }^{23}$ See, as the most representative, Francisco Javier Conde, Teoría y sistema de las formas políticas, Madrid, (1944) 
main theorist of the concept of "caudillaje." The main ideological justification of this Spanish variant of absolute leadership was theoretically premised on the transcendence/immanence dichotomy, with the former overcoming the latter, so as to underpin the legitimization of the leader using a genuine updated source from the Spanish historical tradition through its best interpreter. This theoretical construction derives from the Schmittian critique of Kelsen's attempt to construct an order of abstract norms. It was fundamental to provide the "caudillo" of Spain "by the grace of God and only responsible to God and History" with an elaborate legitimizing political theory equivalent to those that crowned the Duce and the Führer's totalitarian regimes.

Conde's familiarity with Schmitt owes much to a fellowship to study in Berlin in the early $30 s^{24}$ that he obtained from the Council of Extension of Studies and Scientific Research (JAE). In this, he was not alone: the work of Conde, as well as those of other scholars who also contributed to legitimizing the Franco regime's political and foreign policy, stems from the establishment in 1907, under the presidency of the Nobel laureate S. Ramón y Cajal, of an institutional attempt at modernizing Spanish science that was evidently inspired by the Krausism of the Institución de Libre Enseñanza ${ }^{25}$ (1876-1936). The intellectual work of Kelsen's translator, Luis Legaz Lacambra (1906-1980), was also directly relevant to the evolution of Spanish international legal academia during this period. Legaz was also among the elite of legal scholars who, in a country with a $32 \%$ illiteracy rate in 1930, had benefited from periods of scientific research at the University of Vienna thanks to the Council of Extension of Studies. Together with Antonio Truyol y Serra (1913-2003), he was one of the Spanish legal philosophers of his academic generation who developed a keener interest in international legal matters. ${ }^{26} \mathrm{He}$ was also, along with Conde, one of most remarkable political and legal theorists of early Franquismo, ${ }^{27}$ and in the early 40 s became the main Spanish theoretician of the single party with his Introduction to the Theory of the Syndicalist-National State, in which he builds on the crisis of the liberal State to defend the theorization of the single party as a militant ecclesia. ${ }^{28}$

Less than ten years before, however, Legaz had mainly been known for being a gifted student of Kelsen, to whose work he had devoted his doctoral dissertation. ${ }^{29} \mathrm{He}$ also soon distinguished himself as the prologue writer and translator into Spanish of an abridged version of Reine Rechtslehre in 1933 and, soon afterwards, of Kelsen's General Theory of Law, among other works. ${ }^{30}$ By the outbreak of the Spanish Civil War, he had already published various essays on international legal issues. The themes of these essays ranged

${ }^{24}$ See Alberto Reig Tapia, "Aproximación a la teoría del caudillaje en Francisco Javier Conde" 69 Revista de Estudios Políticos (nueva época), (1990) pp. 61-81.

${ }^{25}$ For an introduction, see Elías Díaz, La filosofía social del krausismo español, Edicusa, Madrid, (1973).

${ }^{26}$ See, e.g., Luis Legaz Lacambra "El Derecho internacional en el pensamiento de Ortega y Gasset" 111 Revista de Estudios Políticos (1960) pp.5-41.

${ }^{27}$ See Luis García Arias, "Perfil humano, universitario y científico del profesor Legaz y Lacambra" in Estudios Jurídico-Sociales, Homenaje al profesor Luis Legaz y Lacambra, Universidad de Santiago de Compostela, 1960, pp. 15-81, at 17.

28 Luis Aurelio Gónzalez Prieto, "La concreción teórica del partido único español franquista" 141 Revista Estudios Políticos (2008) pp. 41-68

${ }^{29}$ Luis Legaz Lacambra, Kelsen. Estudio crítico de la teoría pura del Derecho y del Estado en la Escuela de Viena, (Prol. Luis Recaséns Siches), Casa Bosch, Barcelona, (1933).

30 By the 30s and early 40s, Legaz's contribution to scientific translations into Spanish was considerable. This includes his prologues, epilogues and "additions" to works by Kelsen, Mirkine-Guetzèvitch, Sauer, Mayer, Holstein, Larenz or Mosca among others. 
from an examination of the validity of international law in defense of the unity of the universal legal order, pace Alfred Verdross, ${ }^{31}$ to a long commentary on the primacy of international law over domestic law pursuant to Article 7 of the 1931 Spanish Constitution, under the scholarly inspiration of the works of Francisco Suárez. ${ }^{32}$ In 1934, his essay "The Primacy of the Spiritual in the Construction of International Law: the sociological-axiological basis of nationalism and internationalism" appeared. ${ }^{33}$ This was published in an edited volume that gathered together a number of works that emerged from a Conference celebrating the Founding Act of the Catholic Union of International Studies of the Spanish Group of the Union of Fribourg. ${ }^{34}$ Legaz, who was by then the VicePresident of the International Catholic Student association, contributed a piercing analysis of a series of inter-war authors and international legal debates. These fit in perfect consonance in a book where the Spanish expression "entrechocar de civilizaciones" (meaning literally "clash of civilizations") is employed to refer to the looming threat posed by the crisis of the League of Nations ${ }^{35}$ in view of the rise of East Asia, North America and other regions of the world.

Legaz had kept himself at a prudent distance from the legal philosophy of NationalSocialism, a subject to which he had devoted an essay published during the $2^{\text {nd }}$ Spanish Republic (1931-1936), noting that "one cannot applaud with a rigorous ethical criterion the curious mix that [National-Socialism] engenders between transpersonalism of a high idealist connotation and the infra-personalism of biological taints". ${ }^{36}$ However, the influence of National-Socialist legal theory would soon become apparent in Legaz's academic production during the Civil War. The 1936-1939 Spanish civil conflict found Legaz collaborating with the Section of Studies of the Ministry of Organization and Unionist Action, established by Franco's Government in Burgos, ${ }^{37}$ as well as with Jerarquía (1937-1938), the highly representative "black journal of the Falange". Profoundly embedded in the doctrine of the Movimiento Nacional, Legaz's work in the aftermath of the Civil War was depicted by its own author as an evolution of "the theory of justice to the question of personalism and transpersonalism, taking a personalist position combined with a sociological universalism". ${ }^{38}$ Such a sociological orientation may be the result of the influence on Legaz's output of José Ortega y Gasset (1883-1955), to whose perspective of "international law as an ensemble of norms which usurp the real international law" Legaz dedicated a long study some years later. ${ }^{39}$ This sociological perspective became dominant in his work during the first half of the 40 s. His social organicism, partly inspired by the

31 Luis Legaz Lacambra, "La validez del Derecho Internacional (Estudio de teoría jurídica pura)” Universidad Vol. 8 (1931).

32 Luis Legaz Lacambra "Las garantías constitucionales del Derecho internacional" Revista de Derecho Público, Madrid (1933)

${ }^{33}$ Luis Legaz Lacambra "Las primacía de lo espiritual en la construcción jurídica internacional. Las bases sociológico-axiológicas del nacionalismo y del internacionalismo" in Estudios Internacionales. Publicaciones del Grupo Español de la Unión de Friburgo, Madrid (1934))

34 See Pedro Sangro y Ros de Olano, "La unión católica de estudios internacionales" in Estudios Internacionales. Publicaciones del Grupo Español de la Unión de Friburgo, Madrid (1934) pp. 9-26.

35 Ibid, at 20.

36 Luis Legaz Lacambra, "La filosofía jurídica del Nacional-Socialismo", 1 Universidad XI (1934).

37 During the war, Legaz collaborated with the Section of Studies of the Ministry of Organization and Unionist Action established in Santander. Of this period is his Cuatro estudios sobre sindicalismo vertical, Zaragoza (1938).

38 Aditional note to Sauer's Filosofía Jurídica y Social quoted in Luis García Arias op.cit. at 28.

${ }^{39}$ Luis Legaz Lacambra, "El Derecho internacional en el pensamiento de Ortega y Gasset" 111 Revista de Estudios Políticos (1960) pp.5-41 at 24. 
work of G. Gentile, ${ }^{40}$ led to his interest in the philosophical underpinnings of Labor Law and social policy, ${ }^{41}$ which was Legaz's main contribution to the construction of the new Spanish state in the very early years of Franquismo. Legaz's magisterial influence continued to partly undergird the philosophical orientation, and the related selection of topics, ${ }^{42}$ of the new Spanish doctrine of international law forged in this early period of "fascist mimesis" in the following years.

Epitomized by his influence on Conde and Legaz's work, the early reception of Schmitt, which was, conceivably, "not comparable to the reception of any other European intellectual associated with the European fascist regimes", ${ }^{43}$ marks the peak of the 19391942 period of "fascist mimesis" in Spanish legal academia. A number of essays on international themes appeared in the pages of the scholarly journal of the Falange's brain trust, Revista de Estudios Políticos, during this early period of maximum exposure to the ideological underpinnings of the new order. This internationalist scholarly production combined news of legal developments in foreign jurisdictions with articles tackling "the radical transformation of Spanish law and essays on totalitarian legal scholarship". ${ }^{4}$ Consonant with the defining international and domestic political atmosphere of the time is how the leading article of the first issue in 1941 featured the Prologue to "Reivindicaciones de España" alongside a translation of Schmitt's work .45 This book had been awarded the Spanish National Prize for Literature in 1941 for elaborating in extenso on the legal-historical titles that supported the Franco regime's neo-colonialist pretensions. Alfonso García Valdecasas (1904-1993), who had been one of the founders of the Spanish Falange, and the first director of the Instituto de Estudios Politicos, in his Prologue strongly criticizes "sinister groups of increasing influence who are systematically opposed to anything meaning Spanish affirmation: Marxists, republicans, separatists, all of them joined by the same idea: abandoning all foreign enterprise," 46 which was how previous governments had left Spanish foreign policy. ${ }^{47}$ It is exemplary of Valdecasas' special ideological attention to competing political factions within the regime how he impregnates his Falangist rhetorical position with the argument that the book's defense of the historical legitimacy of the Spanish expansionist imperialist thesis is perfectly compatible with the isolationist spiritual autarchy that informed the ultra-nationalist creed captured in the "noli foras ire ... in interiore Hispaniae habitat veritas" of Angel Ganivet (1865-1898). Indeed, the work of this Spanish diplomat, who had penned the Spanish Idearium (1898) which was published in the same year as the Spanish-American war, also the same year that Ganivet committed suicide by throwing himself into the frozen water of the river Dvina in Riga, was one of the inspiring pillars of the new regime's ideological rhetorical architecture. This rhetoric was based on the discursive articulation of a gradual process of cultural reinvention of a strengthened Spanish national identity

${ }^{40}$ Luis Legaz Lacambra “La filosofía jurídica de Giovanni Gentile” Revista de la Universidad de Santiago, 1941.

41 Luis Legaz Lacambra, Introducción a la teoría del Estado nacionalsindicalista, Barcelona (1940), Estudios de doctrina jurídica y social, Barcelona (1940), Lecciones de Política Social, Santiago de Compostela (1946).

42 Vid section II (infra).

${ }^{43}$ Lopez García, op.cit., p.140.

44 Menendez op. cit. p.345 “

45 Alfonso García Valdecasas, "Política Exterior" Revista de Estudios Políticos, 1 (1941) pp. 7-16.

${ }^{46}$ Ibid. at 11.

47 For the political mapping of early Franquismo, see: Julio Gil Pecharromán, La política exterior del Franquismo: Entre Hendaya y El Aaiún. Ed. Flor de Viento (2008). 
that began to take form at the beginning of the $20^{\text {th }}$ century. ${ }^{48} \mathrm{~A}$ crisis of national identity had deeply influenced the political and intellectual life of the country since the so-called "Disaster of 1898", which is the household term by which Spanish public opinion came to know the loss of the last remnants of what had once been the first Empire, over which the sun was never to set. Many philosophers and thinkers busied themselves over the "Spanish problem," developing it from a concern of the new century into a psychologically deeply-rooted cultural and ideological phenomenon. This historical background contributed to the radicalization of a series of conservative and traditionalist ideological notions, some of which had earlier seeped into Spanish rightist ideology from the discourse of disillusioned post-1898 "regenerationism". Nationalism itself became reinforced by the common fascist core myth of national regeneration channeled along the vectors of "Spain's spiritual mission (...) and the belief in an essential, as opposed to plural, Spain whose roots lay in Castille and Catholicism". ${ }^{49}$ This ideological imagery found a political echo in the second of the Falange's 27 program points, in which Primo de Rivera portrayed Spain as having a "unity of fate in the universal". 50 A deeply enraged militant post-Civil War anti-Marxism and anti-intellectualism came to complete the ideological triad of pillars sustaining the early Franco regime's constituency. ${ }^{51}$

A better understanding of this scholarly period cannot, however, be reached without taking into account Spanish foreign policy's "Axis temptation"52 during World War II, and nor the veiled, but extremely crude, internal political struggles that were taking place at the time between the diverse factions of the Generalísimo's highly heterogeneous victorious coalition in the aftermath of the Civil War. Reivindicaciones de España was, however, far from being the only work produced by Spanish international lawyers that put itself at the service of an imperially oriented Spanish foreign policy agenda in this period of ideological affinity with the Axis powers, which was compounded by Franco's gratitude for Italian and German military aid during the recent Civil War, ${ }^{53}$ Spain's onerous external financial debt to the civil war allies, and last but not least tropism spurred by the fascist regime's comparatively successful models of economic and political management of the period of stagnation that had followed the crash of 1929. Some international lawyers were keen to contribute to the nationalist front and the exaltation of Spanishness. Among them was José Yanguas Messía (1890-1974), one of the most influential international lawyers to occupy a chair immediately after World War I, ${ }^{54}$ who had been Minister of Foreign Affairs in Miguel Primo de Rivera's dictatorship and soon became an active member of the Francoist Burgos government's Junta de Defensa Nacional during the Civil War. Other distinguished Spanish international legal academics produced a range of similarly

48 Ibid., at 213

49 Vid. Sebastian Balfour, "The Loss of Empire, Regenerationism, and the Forging of a Myth of National Identity" in Spanish Cultural Studies: An Introduction. The Struggle for Modernity, ed. by Helen Graham and Jo Labanyi, Oxford University Press, London (1995) pp.25-39 at 29.

${ }^{51}$ See Pedro Carlos González Cuevas, Historia de las Derechas españolas. De la Ilustración a nuestros días. Ed. Biblioteca Nueva, Madrid (2000) at 372-384.

52 Paul Preston, The Politics of Revenge. Fascism and the Military in 20th Century Spain, Routledge, London (1995) at 51-84.

${ }^{53}$ See e.g. Nathaniel Berman, "Le clivage de l'internationalisme face aux guerres d'Espagne et de Bosnie: entre "alliance" et "localization" in N. Berman, Passions et Ambivalences. Le colonialisme, le nationalism et le droit international (Présentation d'E.Jouannet), Eds. A.Pédone (2008) pp.235-275

${ }^{54}$ Adolfo Miaja de la Muela, “In Memoriam: José de Yanguas Messia (1890-1974)" 2 Revista de instituciones europeas, 1 (1975) pp. 5-10 
assertive works on foreign policy issues. In 1939, Puntos cardinales de la politica exterior española was published by Camilo Barcia Trelles ${ }^{55}$ (1888-1977), who had coined the title of "founder of modern international law" for Francisco de Vitoria and had, furthermore, played a fundamental role in the reinstatement of the Salamanca school of international law during the 20s and 30s. Following the transfer of the headquarters of the Spanish Society of International and Colonial Studies (SICS) to the Institute Francisco de Vitoria, where the journal Cuadernos de Estudios Africanos was founded in 1948, other works, like one written by J. Cordero Torres, who had founded the society in 1934,56 relied explicitly on the notion of Spanish lebensraum.

The two coauthors of Reivindicaciones de España both became Ministers of Foreign Affairs of Spain in the following decades. One of them, Fernando María Castiella (1907-1976), was the longest serving Spanish Minister of Foreign Affairs (1957 - 1969) in the 20 $0^{\text {th }}$ century. He was appointed member of The Hague Permanent Court of Arbitration in 1939. He was Director of the SICS at the time he co-wrote Reivindicaciones de España, and his long shadow appears inextricably linked to the organic evolution of Spanish international legal academia during the different adaptive phases of Franco's foreign policy. In 1948, he cofounded the Spanish doctrine's main scientific organ of expression, Revista Española de Derecho Internacional (REDI). The second co-founder was Antonio de Luna (1901-1967), who, according to A. Truyol y Serra, had in the late 20s and early 30s provided the "Spanish doctrine of public international law with something as essential to any discipline as an updated general theory," 57 and later on became the first Spanish member of the International Law Commission. The third co-founder was Federico de Castro (1903-1983), who remains - together with Rafael de Altamira 58- one of the only two permanent Spanish judges at the International Court of Justice. Only a few years before co-founding REDI in 1942-43, Castiella enlisted as a volunteer in the Wehrmach's Einheit Spanischer Freiwilliger, best known as the Blue Division. This military contingent assembled more than 47,000 Spanish volunteers, for whom the fight against communism, especially, in the siege of Leningrad during the $2^{\text {nd }}$ World War was a continuation of the crusade spirit of the Spanish Civil War. The other co-author of Reivindicaciones de España, José Maria de Areilza (1909-1998), became Minister of Foreign Affairs at the dawn of the Spanish democratic Transition (1975-1976) after a long career as Spanish Ambassador, which was ultimately crowned by his appointment in 1981 as President of the Parliamentary Assembly of the Council of Europe.

Attributing domestic decadence and Spanish foreign affairs' humiliating subjugation to British and French influence, the Spanish territorial claims on Western North Africa contained in Castiella and Areilza's book have been historiographically reported to constitute a casus belli for the Franco regime to enter the $2^{\text {nd }}$ World War alongside the Axis powers. After Spain's forced withdrawal from its last overseas colonies in the aftermath of

55 Camilo Barcia Trelles, Puntos cardinales de la política internacional española, Ed. Nacional, Madrid, (1939). 56 José María Cordero Torres, Aspectos de la misión universal de España, Vicesecretaria de Educación popular. (1942) See also Zacarías García Villada, El destino de España en la Historia Universal, Ed. Cultura Española, Madrid, (1940).

57 See Truyol y Serra, “Don Antonio de Luna García (1901-1967)”, in Estudios de Derecho Internacional Homenaje a D. Antonio de Luna (1968).

${ }^{58}$ See Yolanda Gamarra, Rafael Altamira, "Un historiador del Derecho en el Tribunal Permanente de Justicia Internacional (1921 - 1939)" Revista Internacional de Pensamiento Político (2011) pp. 50-70. 
the 1898 American-Spanish war, the substitute North-African orientation of Spanish foreign policy was initially facilitated by Spain's role as an equilibrium factor in England and France's contest for the Western Mediterranean. ${ }^{59}$ Spain's long-standing competition with France in North Africa extended over a period of three decades and underwent various fluctuations, including a military struggle against Abd-el-Krim, the leader of a nationalist uprising in the Rif province in the 20s. This historical background was deeply felt by the Africanista General Franco and paved the way for the Spanish neo-colonial claims during the period of fascist mimesis. The Spanish territorial demands included the return of Gibraltar, the extension of Spanish sovereignty over French Morocco and Tangiers, and the expansion of the Spanish Sahara, the Oran region of Argelia, territories around the Red Sea and Conchinchina, and Spanish Guinea. During the long and welldocumented Spanish-German negotiations over entering World War II, these colonialist pretensions were mainly addressed to the bargaining chip of French Morocco. Confronted with the dilemma of needing to reconcile conflicting demands by potential allies, these plans were ultimately halted by Hitler's strategic calculation of a likely risk of the French colonies deserting from Vichy's Metropolitan France ${ }^{60}$ if Germany agreed to the Spanish demands. Reported as one of the various junctures that might have decided the fate of the Second World War, these failed negotiations were soon to be followed by a new focus of the Axis' war effort on the Russian front. Yet, in an almost ironic historiographical twist of events, the Spanish imperialist pretensions contained in Areilza and Castiella's book were later used by the regime to spread the myth of one of Franco's greatest historical triumphs in Spanish public opinion. To the latter, Franco was portrayed as the leader who, by conditioning his belligerence to the fulfillment of those neo-imperialist demands, "was able to say no to Hitler," or at least "not yet," and thus helped to cunningly preserve the shattered Spain from the horrors of World War II. By 1942, the entry of the United States in the Second World War and the British victories in North Africa had led the Caudillo to accept that "there was no territorial compensation which could justify the risks now involved in going to war". ${ }^{61}$ Nevertheless, he apparently continued to reserve the possibility to be exercised "after the worst of the fighting was over, but before the division of the spoils". ${ }^{62}$ The appointment of F. Gómez-Jordana63 as new Minister of Foreign Affairs in September 1942 initiated a gradual re-orientation of the regime, and a slow move towards neutrality, ultra-Catholicism and fierce anti-communism. This resulted in the traditional right progressively taking over from the steady decline of the "new right" of the Falange. With the dream of the New Order and the New Europe ${ }^{64}$ already vanishing after the success of the D-Day landings in June 1944, and the increasing threat of an extension of

59 See Susana Sueiro Seona, "La política exterior de España en los años 20: una política mediterránea con proyección africana" in J.Tussell, J.Aviles \& R. Pardo (Eds.) La política exterior de España en el siglo XX, Ed. Biblioteca Nueva (2000), pp.135-157.

${ }^{60}$ See Norman J.W. Goda "Franco's Bid for Empire: Spain, Germany and the Western Mediterranean in World War II" in Raanan Rein (ed.) Spain and the Mediterranean since 1898, Franck Cass London \& Portland, (1999), pp. 168-194 and e.g. Wayne H. Bowen Spaniards and Nazi Germany. Collaboration in the New Order, University of Missouri Press, Columbia and London (2000)

61 Paul Preston, The Politics of Revenge. Fascism and the Military in 20th Century Spain, Routledge, London (1995), at 78.

62 Ibid., at 62.

${ }^{63}$ See Gil Pecharromán op.cit at 91-95 on the Begoña bombings and the reform of the Ministry of Foreign Affairs introduced by Gómez-Jordana.

64 See Rafael García Pérez, "La idea de la "Nueva Europa" en el pensamiento nacionalista español de la inmediata posguerra 1939-1944" Revista del Centro de Estudios Constitucionales 5, (1990) pp. 203-240. 
the liberation struggle to communist guerrilla warfare and partisan activity in Spain, ${ }^{65}$ the later stages of the war witnessed a cautious Spanish diplomatic realignment with the Allies, ultimately oriented towards the survival of Franco's regime.

The transplant of Schmitt's theoretical work to Spain can be interpreted as an opportunist intellectual building block for the regime's legitimization at a time when "those wellversed in fascist and nazi theories could push forward the half-baked ideas of Spanish reactionary thought into a more coherent (...) canon". ${ }^{66} \mathrm{~A}$ better understanding, however, of the endurance of the Schmittian Spanish relationship beyond early Francoism can be gained from an examination of the nature of the Spanish regime as a "fascistised dictatorship" or, if preferred, as the "missing link between fascist dictatorships and authoritarian regimes". ${ }^{67}$ It is this characterization that allows us to better grasp the ulterior process of gradual ultra catholic-oriented de-fascistization that accompanied the evolution of the Franco regime under the influence of both domestic political tensions and an ever-changing international political scenario. Moreover, this description of the Franco regime also allows better understanding of the limits within which that very gradual defascistization process took place. The slow post-1943 political-ideological turn in the works of Spain's intellectual elite is epitomized by the evolution of the most emblematic Falangist cultural journal, El Escorial. This was run by a group of high-profile intellectuals under the direction of Pedro Laín Entralgo. ${ }^{68}$ Since its inception in 1940, its stated purpose had been that of contributing to the search for theoretical, ideological and cultural foundations for the new Spanish totalitarian state under the great inspiration of José Antonio Primo de Rivera, who was portrayed as the "supreme director of our enterprises". This intellectual endeavor involved the journal's editorial lobbying in favor of Spanish entry in the $2^{\text {nd }}$ World War in defense of the New Order, upholding the Spanish territorial claims and defending the need to foster a national syndicalist community to construct a totalitarianism that, by blending existing ideas, would contribute to forging a new "synthesis unclassifiable as either right or left, and thus uniquely positioned to solve the problems of the modern age". By the mid-40s, El Escorial had begun, however, to leave the political realm, and to re-orientate its work towards literary and historical topics. This reorientation went hand in glove with the new prominence acquired by the Catholic and ius-naturalist perspectives which, inspired by the works of Vitoria, Luis Vives and F. Suarez, ${ }^{69}$ had run parallel to the journal's Falangist credentials. This Spanish purist line of national thought found - as the next section examines in more detail - fertile soil in the works produced on the Spanish doctrine of international law in the next decades.

While, as R.Griffin notes, "para-fascism and true phalangism would become increasingly peripheral to what remained at heart an authoritarian conservative system", ${ }^{70}$ the intellectual activity of the Instituto de Estudios Políticos (IEP) and other parallel satellite thinktanks associated with the Movimiento continued to set the highest academic standards for the regime and to influence its most important legislative emanations. Four

65 See Geoffrey Swain, "Stalin and Spain, 1944-1948" in Christian Leitz and David J. Dunthorn Spain in an International Context, 1936-1959, Berghahn Books, New York-Oxford (1999) pp.245-131.

${ }^{66}$ See Menendez op.cit, p.350.

67 Ismael Saz Campos, Fascismo y Franquismo, Publicaciones de la Universidad de Valencia (2004) at 90.

${ }^{68}$ See Pedro Laín Entralgo, Desgargo de conciencia (1930-1960) Barcelona, Barral (1970)

69 Pedro Carlos González Cuevas, Historia de las Derechas españolas. De la Ilustración a nuestros días. Ed. Biblioteca Nueva, Madrid (2000) at 374-378.

${ }^{70}$ Roger Griffin (Ed.), Fascism, Oxford University Press (1995), at 185. 
other publications associated with the Instituto de Estudios Políticos joined Revista de Estudios Políticos (1941), the flagship of the Falange's thinktank: Revista de Política Internacional (1950 to 1979), Revista de Administración Pública (1950), Revista de Economía Política (1945-1983) and Revista de Política Social (1949-1985). This group of journals contributed to extending beyond the period of fascist mimesis the hope, as noted by the prologue writer of Reivindicaciones de España, of "an experimental period in the constitution of the State"71 conceived of as a "totalitarian instrument at the service of the integrity of the motherland" 72 based on the "the original characters of the Spanish political conception,"73 one that is "for us not only physical, territorial or geographic, but also a moral one". ${ }^{74}$ This prevailing moral conception of the Spanish motherland had already been enshrined in the original editorial of Revista de Estudios Politicos, which pledged the journal to be at the service of the "whole and radical truth" of the Movimiento Nacional in the construction of a functional knowledge that "now more than ever is required from us to be urgently sure". ${ }^{75}$ Both Francisco J. Conde - the main Spanish disciple of C.Schmitt in the early period - and Luis Legaz Lacambra - the most gifted Spanish student of Kelsen in the 30s - served in the following years as directors of the Instituto de Estudios Políticos, which continued to play a key role through its various journals, reports, legal opinions and pre-legislative projects of political and legal transcendence during the long 40 years of Franco's regime.

\section{THE VITORIAN AFTERMATH - THE SPANISH ACADEMY OF INTERNATIONAL LAW FROM AUTARCHIC OSTRACISM TO INTERNATIONAL RE-ALIGNMENT}

"Order, unity and endurance" - such was the strategic formula that Luis Carrero Blanco, ${ }^{76}$ by then Sub-Secretary of the Spanish Presidency, suggested to General Franco in 1945 to countervail the growing international hostility towards the only pro-Axis regime that had survived the end of the Second World War. ${ }^{77}$ These guidelines coincided with the management of Spanish foreign policy by Catholic elites under the direction of the new Spanish Minister of Foreign Affairs, Alberto Martín Artajo (1945-1957). These recommendations also had a profound influence on the thematic choices of Spanish international law academia during the period of Spanish so-called "autarchy" between 1945 and 1953. In these years, the launching of Revista Española de Derecho Internacional (REDI) and of Revista de Política Internacional gradually (although never completely) deprived Revista de Estudios Politicos (REP) of its original editorial mandate to cover both foreign policy and legal-international relations. ${ }^{78}$ From 1945 to 1949, the international plane was covered by an international chronicle in Revista de Estudios Políticos (REP). One of the authors of the conspicuous Falangist hymn Cara al Sol, Pedro Mourlane Michelena,

\footnotetext{
${ }^{71}$ Alfonso García Valdecasas, “Los estados totalitarios y el Estado español”, p. 24.

72 Ibid. at 26.

73 Ibid. at 32.

74 Ibid. at 27.

75 Alfonso García Valdecasas, “Editorial” 1 Revista de Estudios Políticos (1941), pp.5-6, at 6.

76 Admiral Luis Carrero Blanco was killed in a terrorist bombing orchestrated by E.T.A. under the name “Operation Ogre" when he was Spain's Prime Minister in 1973.

77 Note of the 29th August 1945 in Alberto Martín Artajo's archives: Luis Carrero Blanco, "Notas sobre la situación política" quoted in Florentino Portero "Spain, Britain and the Cold War" in Sebastian Balfour and Paul Preston (eds) Spain and the Great Powers in the 20th Century, Routledge, London and New York (1999) pp.210228 , at 216.

78 Alfonso García Valdecasas, “Editorial” 1 Revista de Estudios Políticos (1941), pp.5-6.
} 
and two noted international lawyers, Luis García Arias and Camilo Barcia Trelles, ${ }^{79}$ were successively charged with the responsibility for this international chronicle. The establishment of Revista de Política Internacional in 1950 was a response by the Instituto de Estudios Políticos to the growing need for specialized Spanish journals on international affairs at a time when Span's international isolation was gradually coming to an end. The launching of Revista de Política Internacional and of Revista Española de Derecho Internacional (REDI) in 1948 led to the disappearance of the international chronicle section from Revista de Estudios Políticos. Many Spanish international lawyers, including Barcia Trelles, ${ }^{80}$ however, continued to contribute articles and essays on international themes to the original flagship of the Falange's "brain trust". ${ }^{81}$ The key role played by Spanish international lawyers in the Instituto de Estudios Políticos during this early epoch of the Franco regime is furthermore evinced by Castiella's appointment as its second Director (1944-1948). Antonio de Luna, the first director of Revista Española de Derecho Internacional (1948-1963), had previously been the director of the Instituto's own division of international politics, and had extensively contributed with articles of an ultranationalistic orientation to the pages of Revista de Estudios Políticos. ${ }^{82}$

Previously, there had been several short-lived attempts at providing Spanish international law academia with a specialized scientific journal. Revista de Derecho Internacional, Legislación y Jurisprudencia Comparada was founded in 1887 by A. García Moreno, and the Marquis of Olivart launched Revista de Derecho Internacional y Política Internacional in 1905. After 1948, the bulk of the specialized Spanish academic production in international law was channeled into the new main organ of expression, REDI. In its first period (19481963), REDI followed the guidelines established by Antonio de Luna, who together with Castiella and De Castro occupied its board of directors. This board oversaw an editorial board onto which all newly appointed Spanish catedráticos of international law were automatically incorporated alongside several representative catedráticos from other legal disciplines, such as Legaz Lacambra and Antonio Truyol y Serra. 83 These first sixteen years of the new journal were thematically ordered around three main centers of doctrinal interest: "the Spanish school of the ius gentium; essays on war and peace; and the problems of war criminality and crimes against humanity". ${ }^{44}$ Also indicative of the endogamous line of continuity between the main Falangist thinktank and the new Spanish international law journal is the fact that Carl Schmitt 85 was the first foreign author to be published in REDI, with a work justifying the occupation of a new world, pace Vitoria, in 1949. Indeed, one of the preferred themes cultivated by Spanish international law academia during the period 1945-1953 was the continuation of the works initiated in the 20s on the "Spanish founders of international law". This orientation fitted well with the, by then, prevailing atmosphere of Spanish nationalist atavistic cultural forms drawn from the

79 See Pedro Mourlane Michelena 24 Revista de Estudios Políticos, November-December (1945). The last international chronicle was penned in issue 44 March/April (1949) by Camilo Barcia Trelles.

80 See e.g. Camilo Barcia Trelles, "El ayer, el hoy y el mañana internacionales" 50 Revista de Estudios Políticos, (1950) pp.135-156.

81 Stanley G. Payne, Falange. Historia del fascismo español, Ed. Ruedo Ibérico, París (1965), at 217.

82 Antonio de Luna, “España, Europa y la Cristiandad”, 9-10 Revista de Estudios Políticos, 1943, pp.41-98.

83 See A. Remiro Brotons,"El discreto encanto - y desencanto - de la Revista Española del Derecho Internacional (1948-1978)" in Estudios de Derecho Internacional. Libro-homenaje al Prof. A. Miaja de la Muela, vol. I (1979), at 123-124.

84 Ibid. at 129.

${ }^{85}$ C. Schmitt, "La justificación de la ocupación de un nuevo mundo (Francisco de Vitoria)", Revista Española de Derecho internacional (1949) 13-44. 
mythology of Reconquest, Counter Reformation and Empire, and with the myth of the Crusade against the "anti-Spain" embodied in the Civil War for the purpose of national reunification. Combined with political repression and economic autarky, this unwitting cultural mood paved the way along what the regime saw as a "healthy road to modernity".86 The cultivation of the study of the Spanish priests who had "founded" international law was, moreover, perfectly consonant with the image of Spain projected by Franquoist foreign policy as a natural-law oriented, ultra-catholic and antiMarxist stronghold.

In 1943 the National Delegation of Propaganda had issued a series of intellectual directive guidelines that had seen it fit to remind Spanish academia in peremptory terms that "the Spanish state is exclusively grounded on principles, political norms and a philosophical basis of a strictly national character. In no circumstance will it be allowed to compare our State with other States which might appear similar, and even less to extract consequences of supposed foreign adaptations to our country"..$^{87}$ These instructions were oriented at warning the Falange's pro-Axis intelligentsia of the convenience of turning their attention towards a purist traditional Spanishness, along the lines of the "noli foras ire ... in interior Hispania habitat veritas" of Angel Ganivet. These guidelines fostered the study of international legal history and the Spanish imperial past during the autarky period by Spanish international lawyers. This scholarly development benefitted from the availability of both primary and secondary academic sources in a period of international isolation and censorship, and turned out to be a convenient theme from the perspective of an unproblematic professional development of scholars' activities in Franco's new Spain of the 40s. Representative of this epochal shift of focus from the period of "fascist mimesis" is Legaz Lacambra's work from the mid-40s onwards. In this period, Legaz's interest in international legal issues partially distracted him from his focus on labor law and social policy, which had characterized his intellectual production during the Civil war and its immediate aftermath. Although coherent with the "totalitarian humanism" that characterized his work during this period, Legaz devoted more attention to the historicaldoctrinal realm during the late 40s. Representative of this partial new orientation are Legaz's book Man and War (1944), which revisits the notion of just war in the Spanish classics, and his articles on "The Modern and the Medieval in Vitoria (1946) and the "Foundation of ius gentium in Suarez" published in REDI in 1948.

The revival of studies on the Siglo de Oro in Spanish international law academia was, furthermore, connected with more concrete Spanish foreign policy goals. These included the defense of Hispanidad, which regained importance during the autarky period as part of a sound diplomatic policy towards South-America. Indeed, Franquismo, since its very origins, had built its rhetorical policy on earlier efforts to foster relationships with Latin America. This orientation was akin to the mystique of the new Spanish imperial vision spurred by the Spanish Falange under the banner "Through Empire to God," which was a slogan aiming to portray Spain as a moral supervisor and a cultural and religious guide to its ancient colonies under the fraternal cloak of the notion of Hispanidad. The establishment of The Council of the Hispanidad in 1940 reflects the importance that the

86 See Mike Richards, "The Material Reality of Power" in Helen Graham and Jo Labanyi (eds.) Spanish Cultural Studies: An Introduction. The Struggle for Modernity, Oxford University Press, London (1995), pp.173-182

${ }^{87}$ Fernando Díaz-Plaja. La España franquista en sus documentos. Plaza \& Janés. Barcelona (1976), at 139-140. 
new regime attributed to this vector of its foreign policy. The new Council, which was financed by the Spanish Ministry of Foreign Affairs, was an initiative of the so-called "Foreign branch of the Falange". It was charged with the mission of "studying and resolving the common spiritual and material needs of the Peoples of our lineage" 88 . The very term Hispanidad was trademarked by the Spanish Ministry of Foreign Affairs in a single-articled Ministerial Order in May 1941. According to this telling example of how ideological notions may become normatively conceptualized, "While [Hispanidad] means the ensemble of nations that integrate the Hispanic world, it also embodies their peculiar spirit and their understanding of life as well as their common historical tradition and superior universal destiny. It is thereby forbidden to freely use the term "Hispanidad," which cannot be employed as a trademark in industrial terms or for commercial establishments". The General Assembly Resolution 39 (I) of 12 December 1946 opened a new era in Spain's international isolation. It also marked the abandonment of the Spanish imperial ambitions of the period of fascist mimesis and fostered the design of "policies of substitution" that could allow the Franco regime to cope with the new foreign policy realities of the autarchic period. Consonant with Carrero Blanco's guidelines of "unity, resistance and endurance", these "policies of substitution" were designed to allow for the diplomatic privileging of certain regions and allies in order to advance the "Spanish question" at the United Nations through the gradual scratching of votes from the Arab world and Latin America. One of the first measures adopted by the elite Catholic-oriented new Ministry of Foreign Affairs under the direction of A. Martín Artajo was that suppressing the Council of Hispanidad in 1945 because its imperialist aura created discomfort in Latin America. Although the Council was replaced by the more diplomatically correct Institute of Hispanic Culture in October 1946, a new Ministerial order of 1947 extended the trademark of the term Hispanidad to prohibiting the expressions "Hispanic world, Hispanic culture and any other term of analogous meaning that makes reference to the spiritual community of the peoples of Spanish language". ${ }^{89}$

This focus on Hispanidad and policies of substitution was complemented by a crude antiMarxism. An exponent of the complementary cold Realpolitik diplomatic lenses through which the USSR's foreign policy was attentively examined, José Sebastian de Erice y O'Shea, author of two volumes of Diplomatic Law, ${ }^{90}$ examined "the monstrously antijuridical unfolding between 1945 and 1950 of the so-called "Spanish case"91 at the United Nations in one of the first issues of Revista de Política Internacional in 1950. Taking as his starting point the "rehabilitating" General Assembly Resolution of $4^{\text {th }}$ Nov 1950, De Erice retraces the USSR-led UN's obscure "gambling and deals in corridors"92 that induced the Western historical mistake of falling into the trap of the "completely mendacious and injurious"93 diplomatic strategy designed by Russia and its satellites vis-à-vis the only country that had effectively proven itself able to resist as a "European stronghold against Russian imperialism" with the purpose of appeasement. ${ }^{94}$ The work of this first Spanish

\footnotetext{
${ }^{88}$ Julio Gil Pecharromán, La política exterior del franquismo: Entre Hendaya y El Aaiún. Ed. Flor de Viento (2008), at 87

${ }^{89}$ See Pecharromán, op. cit. note 67, at 162.

90 José Sebastián de Erice O’Shea, Derecho Diplomático. 2 vols. Madrid, (1954).

91 José Sebastián de Erice O'Shea, “España y las Naciones Unidas” 1 Revista de Política Internacional 4 (1950), pp. $9-49$ at 9 .

92 Ibid., at 15.

93 Ibid., at 11.

94 Ibid., at 12.
} 
Ambassador to the UN (1955) presents in detail and by providing diverse documentary annexes the gradual evolution of the votes diplomatically scratched in favor of the "recognition of the truth of our motherland"95 (from 51 states against in 1945, to 6 votes in favor in 1946, 16 in 1947, 26 in 1949 and finally 38 in 1950) as a long effort and great success of the Spanish policies of diplomatic substitution both towards South America and countries of the Arab world against the odds of the fierce anti-Spanish international strategy led by international communist forces. We find the same insistence on antiMarxism and Hispanidad in the 1960 official book commemorating 25 years of the National Movement, with a prologue by General Franco himself. Here, the Spanish diplomat Gonzalo Fernandez de la Mora (1924-2002) presents a balance sheet of a quarter of a century of Spanish foreign policy, which he portrays as "always ancillary to domestic policies". After stressing, once again, the "blinding evidence" of Spanish neutrality in World War II and defending the strategic nature of Franco's appeasement policy vis-à-vis Hitler, ${ }^{96}$ he notes that "Spanish foreign policy in the last quarter of a century has not been pragmatic but founded on spiritual and historical affinities - the Hispanidad, the Iberian Bloc, Hispanic-Arab friendship - and inspired by a fundamental ideological position: anticommunism". ${ }^{97}$

The return to the cultivation of historical-legal studies during the autarky period of Spanish international law benefitted greatly from earlier works produced by Spanish scholars on this area in the $20 \mathrm{~s}$ and $30 \mathrm{~s}$ and before. Indeed, the reinterest in $16^{\text {th }}$ century Spanish legal-theological work during the 40 s was built on a soil that had previously been cultivated by some of the members of the "first scientific generation" 98 of international lawyers in Spain which emerged from the extension of international law studies to universities other than Madrid by a Royal Decree of 1883. Such a history-oriented renewal was also one of the vectors of the development of Spanish internationalist academia during the interwar years. The raison d'être of this earlier inter-war scholarly thematic interest was not alien to Span's foreign policy orientation to its ancient colonies at that time. The scientific revival of the Salamanca school owes much to the personal contribution of the author of the book World Peace and the Imperialism of Oil ${ }^{99}$ in 1925. In this work, Camilo Barcia Trelles (1888-1977) examines the global reach of transnational oil companies by paying special attention to their contribution to pushing forward "an, overwhelming, scarcely scrupulous imperialist trend, which puts the activity (of American foreign policy) at the service of interested parties, even if the latter might lead to an intromission into the spheres of independent sovereignties"100. Featured as the second of the courses taught at the Section for American Studies at Valladolid University, Barcia

\footnotetext{
95 Ibid., at 29.

96 Gónzalo Fernández de la Mora, "La política exterior de España” in Ed. Instituto de Estudios Políticos, Madrid (1961) pp. 65-92 at 70-71.

97 González de la Mora, op.cit. pp.90-91.

98 I extrapolate to the Spanish arena the terminology used in Martti Koskenniemi, The Gentle Civilizer of Nations. The Rise and Fall of International Law 1870-1960, Cambridge University Press, Cambridge (2001). See also Ignacio de la Rasilla, "A la sombra de Vitoria - La nueva edad de plata de la tradición española de Derecho Internacional” in Gamarra, Y. \& De la Rasilla, I. (eds.) Historia del Derecho Internacional en España, Vol. I, Ed. Ariel, (2012).

${ }^{99}$ Camilo Barcia Trelles, El imperialismo del petróleo y la paz mundial, Ed. Sección de estudios americanistas, Valladolid (1925).

${ }^{100}$ Ibid., at 248.
} 
Trelles's work was preceded by his examination of Postwar American Foreign Policy101. Barcia Trelles had been a student of Aniceto Sela y Sampil (1863-1935), a very progressive international lawyer affiliated to the Institution for Free Teaching (ILE) ${ }^{102}$ and a pioneer of the activities of university extension at Oviedo University in the 1910s, who later became the first President (1929-1935) of the Association Francisco de Vitoria. Barcia became one of the first Spanish international lawyers to profit from the establishment of the Council of Extension of Studies in 1907, thanks to which he was able to study in Brussels (19111913) with Ernest Nys, who had been one of the drivers of the revival of Vitoria as founding father of the discipline, ${ }^{103}$ and, later, in Berlin (1913-1914) until the outbreak of World War I. Just after the end of the war, Barcia Trelles became part of the post-war generation of Spanish catedráticos of international law. His three courses at The Hague Academy, devoted to Francisco Suarez, the theologians of the $16^{\text {th }}$ century, and Fernando Vazquez de Menchaca respectively, ${ }^{104}$ played an important role in the revitalization of the "humanist" interpretation of the $16^{\text {th }}$ and $17^{\text {th }}$ century Salamanca school strand of thought, which also benefited from the valuable help of J. Brown Scott.105

Barcia's works on U.S. foreign policy, which included a course on the Monroe Doctrine at the Hague Academy in 1929 and one at the Salamanca School, were published at a time of both cultural and, to a lesser degree, economic competition between the U.S. and Spain in Latin America. Spanish foreign policy of the 20s was mostly North-Western African in orientation, and the relationship with Latin America was more often than not addressed in "spiritual" and cultural terms, in view of the Spanish material difficulties in competing with other nations in the political and economic arenas. The position of the Spanish Americanists vis-à-vis the former Spanish colonies was articulated by Rafael Altamira Crevea (1866-1951), who was at the time Judge at the International Permanent Court of Justice (1919-1944). Altamira laid claim to a "special and exclusive camp, which is the one we have in common with the peoples of our civilization and our language. In this field, we want neither intervention nor collaboration, which in all likelihood will perturb us. For Spanish Americanists this is a dogma as intangible as the absolute domestic and international independence of all American republics"106. There was a deep connection between the revival of the Salamanca school by Spanish international lawyers and Spanish attempts to come to terms with a sphere of Spanish cultural and linguistic influence in the 20s in Latin America which was beyond the reach of US backdoor imperialism. This orientation contributed to the development of "Hispanic" propaganda, which was inextricably linked to the domestic effects of the "Disaster of 1898" and the ensuing

\footnotetext{
101 Camilo Barcia Trelles, La política exterior norteamericana de la postguerra, Universidad de Valladolid. Publicaciones de la Sección de estudios americanistas, 1. ser., núm. 2 (1924).

102 D. Gonzalez Campos, J.D. Mesa and R. Medina Ortega, "Notas para la historia del pensamiento internacionalista español: Aniceto Sela y Sampil, 1863-1935", op. cit. note 9, pp. 561-583.

${ }^{103}$ See one of his earliest works on this topic: Ernest Nys "Les publicistes espagnols du XVI siècle et les droit des indiens" 21 Révue de droit international et de législation comparée, 532 (1889).

104 See respectively by C. Barcia Trelles, "Francisco de Vitoria et l'école moderne du droit international", RCADI, vol. 17 (1927-II), pp. 109-342; "Francisco Suarez (1548-1617): les théologiens espagnols du XVIème siècle et l'école moderne du droit international", RCADI, vol. 43 (1933-I), pp. 385-553; "Fernado Vázquez de Menchaca (1512-1569): l'école espagnole du droit international du XVIème siècle", RCADI, vol. 67 (1939-I), pp. 430-534.

105 See a rare work in Spanish: James Brown Scott, "El origen español del Derecho internacional moderno", Valladolid, Sección de Estudios Americanistas Serie Quinta número 1 (1928).

${ }^{106}$ Rafael Altamira Crevea, “España, los Estados Unidos y América”, Revista de las Españas, 2o época, no 7-8, Madrid (1927), pp. 175-177.
} 
challenge of modernization, which encouraged a renewal of traditional views on Spanish history and the nature of Spanishness. It is from this cultural frame that the myth gradually emerged of the universalist mission of Spain to bring spirituality to an increasingly materialistic world, which years later would be taken up again by Franquismo in its portrayal of Spain "as the last spiritual rampart of the West" and of "Franco as the sentinel of Western Civilization".

By the time of the Franco regime's gradual diplomatic realignment with the West, Barcia's work was focused on geopolitical analysis of the respective foreign policies of the USSR and US. His approach to the USSR and Marxism is exemplified by the leading article of the first issue of Revista de Politica Internacional, 107 which he wrote on the occasion of the establishment of the Atlantic Pact. Highly influenced by a retrospective reading of H.Mackinder, ${ }^{108}$ Barcia's essay develops a detailed analysis of the history of Russia as a "geocratical power" vis-à-vis the US, which he conceptualized as a "talasocracia". His work was aimed at denouncing the myopia of certain approaches to "this culminating stage of the fight between the World Island and the Periphery world".109 His geopolitical framework portrayed the limited "dissuasive value of the Atlantic Pact" against an "ideological soviet tactic," which he conceived of as a mere "instrument of execution of the great Russian historical geopolitical designs which originated in the times of Peter the Great". ${ }^{110}$ In contrast to what Barcia judged to be a temporarily disorientated US foreign policy, he devoted his analysis to warning about the danger posed to Western civilization by a "messianic" Russia, which at that historical juncture had the "international initiative on its side" and knew perfectly well where it was "orientating its steps"111 in perfect compliance "with certain indeclinable geopolitical laws".112 Barcia distinguished "between communism as an instrument of expansion and Russian imperialism as the final goal of the former",113 before putting forward a number of foreign policy recommendations for US foreign policy makers on Asia114 so as to supplement the "incomplete vision of unity of those who articulated the Atlantic Pact," 115 which was for him the "United States' dialectical suit of armor". ${ }^{116}$

But if Barcia's experiment with the lenses of geopolitical approaches to international relations is characteristic of the autarky period of Spanish international law, his works during the interwar years on the Salamanca School greatly contributed to "La renaissance des classiques espagnols du droit des gens" depicted as "l'un des signes de cette période de l'histoire de la discipline.117 The other two core focuses of Spanish doctrinal interest during a period that has been defined as one of "absolute primacy of the legal perspective

107 Camilo Barcia Trelles, "El pacto Atlántico y las inclinaciones geopolíticas de la URSS" 1 Revista de Política Internacional 4, 1950 pp. 13-52.

108 Ibid., at 38.

109 Ibid., at 36.

110 Ibid., at 52 .

111 Ibid, at 48 .

112 Ibid., at 38.

113 Ibid., at 40.

114 Ibid., at 45-48.

115 Ibid., at 52 .

116 Ibid., at 32

117 Antonio Truyol y Serra, Histoire du droit international public (1995), at 150. 
in the Spanish academic approach to international problems"118 were the League of Nations and inquiries into the nature and characteristics of international society. The parallel renewal of a Spanish historical ius-naturalist tradition was not without influence on shaping Spanish scholars' contribution to the debate in the interwar years on the ultimate foundation of international law. This neo-naturalist revival also extended itself to the European doctrine of the time, which, among others, played an influencing role in anchoring Alfred Verdross' constitutionalist approach to international law. ${ }^{119}$ This perspective, which constituted a departure from Verdross' earlier formal legal theoretical orientation to legal philosophy, amounted to grounding the theoretical foundations of international law in the normative idea of the moral unity of mankind. This conception was based, as Verdross himself proudly proclaimed,120 on a universalistic tradition retraceable to early Spanish scholarship. Antonio Truyol y Serra (1913-2003), the translator of Alfred Verdross' textbook on international law in its different editions from 1955,121 played an important role in the cultivation of the history of the Salamanca school in the autarchic period of Spanish international law. Truyol, who later became Judge of the Spanish Constitutional Court (1981-1990), is the only Spanish catedrático of the $20^{\text {th }}$ century to have successively held chairs of philosophy of law (1940-1957), international relations (the first ever in Spain, established in 1957) and public international law. The work of the young Truyol, which Koskenniemi has referred to as work that "decried the spiritual poverty of positivism and advocated a turn to metaphysics and morality",122 was mainly historical and almost exclusively Catholic ius-naturalist in orientation during the 40 s and early 50s. Like many other scholars of the post-Civil War generation, Truyol's intellectual production in the 40s and early 50s engaged with the works of Saint Augustine,123 Vitoria,124 Suarez,125 the sources of natural law,126 and/or Medieval scholarship.127 The character of the intellectual production of an author who had written on "The State in Rousseau and Lenin"128 just before the outbreak of the Spanish Civil War serves to remind us that the intellectual soil nurtured by earlier generations of Spanish international legal scholars remained a doctrinal land tilled by a maimed farmer for most of the Franco period.

118 Celestino del Arenal,op.cit. note 12 , at 50 and 51

119 The influence of the Salamanca tradition in helping A. Verdross to overcome Kelsenian positivism is expressly noted by Luis Legaz Lacambra in "La influencia de la doctrina de Kelsen en la Ciencia Jurídica española”, Revista de estudios políticos, no 96, (1957),

${ }^{120}$ A. Verdross acknowledged his debt to the Salamanca school in his author's note to the first edition of the Spanish translation of his Völkerrecht: A. Verdross, Derecho Internacional Público (1955), at xii.

${ }^{121}$ Alfred Verdross, Derecho internacional público (transl., bibliography and additional notes by A. Truyol y Serra, Madrid, 1955; $6^{\text {th }}$ ed. in collaboration with M. Medina Ortega (1976).

122 Koskenniemi, The Gentle Civilizer of Nations. Op.cit. at 350

123 See e.g. A. Truyol y Serra, El derecho y el Estado en San Agustín, Editorial Revista de Derecho Privado Madrid (1944).

124 See e.g. A. Truyol y Serra, Los principios del derecho público en Francisco de Vitoria (selección de textos, con introducción y notas), Ediciones de Cultura Hispánica, Madrid (1946).

${ }^{125}$ See e.g. Truyol y Serra, "El objetivismo ético de Francisco Suarez y su influencia en la historia del pensamiento", Actas IV Centenario de Francisco Suarez (1548-1948) II, 1950 Madrid, pp. 107-209.

126 See for example A. Truyol y Serra, Fundamentos del Derecho Natural, F.Seix, Barcelona (1949).

127 See for example A. Truyol y Serra, "La filosofía jurídica y social en la crisis del mundo medieval", Revista Internacional de Sociología, V (1947), no19 (July-September), pp. 135-153.

128 Manuel Medina, "El pensamiento internacionalista del profesor Truyol y Serra", op. cit. note 13, pp.15-28, at 20. 


\section{CONCLUSION}

Generations of Spanish international legal scholars - both past and present ${ }^{129}$ - have on nationalistic grounds contributed to anchoring Vitoria and Suarez, with their Catholic universalism, as the founding fathers of international law. During the period covered by this essay, the very constitutive enshrining of a Spanish tradition of international law along these lines was found at the core of one of the Franco regime's main international foreign policy triumphs during the Cold War. The regime's portrayal of Spain as the last reservoir of European Catholic traditional values after the Second World War and as the only European country that had successfully resisted as a stronghold against the spread of Russian imperialism and Marxism contributed to Spain's realignment with the West. This realignment found a corollary in the signature of a Concordat with the Vatican in August 1953 and of three important economic-military pacts with the US in September 1953. These pacts defined the two fundamental key alliances of Franco's regime in the international world and marked the evolution of Spanish foreign policy until the death of the dictator in 1975. The Vitorian aftermath of the fascist mimesis of Spanish international law lived on, however, far beyond the date that marks the Spanish re-alignment with the West. Apart from a short-lived attempt in the early 60s to set "new premises and partly different problems and methodologies"130 in Spanish international law academia, throughout the whole period of Franquismo the very cover of the Revista Española de Derecho Internacional featured the effigy of Francisco de Vitoria.

\footnotetext{
${ }^{129}$ Pablo Zapatero, "Legal Imagination in Vitoria. The Power of Ideas", Journal of the History of International Law 11 (2009) 221-271.

130 Mariano Aguilar Navarro, "Tareas de la doctrina española de Derecho internacional público", Revista Española de Derecho Internacional, 1964, pp. 501-515, at 502.
} 